\title{
Analisis Pelayanan Gizi Rumah Sakit dengan Pendekatan Health Technology Assessement (HTA)
}

\author{
Dewi Marhaeni Diah Herawati ${ }^{1}$, Anggun Rafisa ${ }^{2}$, Ahmad Yani ${ }^{3}$ \\ ${ }^{1}$ Departemen Ilmu Gizi Medik Fakultas Kedokteran Universitas Padjadjaran \\ ${ }^{2.3}$ Program Studi Ilmu Kesehatan Masyarakat Fakultas Kedokteran Universitas Padjadjaran
}

\begin{abstract}
Abstrak
Prevalensi malnutrisi di rumah sakit masih sangat tinggi, diduga pelayanan gizi menjadi salah satu penyebabnya. Penelitian bertujuan untuk melakukan asesmen pelayanan gizi rumah sakit dengan pendekatan HTA. Desain penelitian studi kasus dengan pendekatan mixed method concurrent embedded. Pemilihan sampel kualitatif secara purposive sampling, sedang kuantitatif dengan total sampling. Penelitian dilakukan pada bulan September-Desember 2014 di RS vertikal (Situs 1) dan RS skunder swasta (Situs 2). Analisis data kuantitatif dilakukan secara deskriptif sedang kualitatif secara content analysis. Peran manajer pada kedua situs cukup baik, hal ini dapat dilihat dari dibentuknya tim terapi gizi rumah sakit dan peningkatan kualitas SDM. Teknologi pelayanan gizi pada kedua situs belum memenuhi standar Kemenkes. Persepsi pasien terhadap mutu pelayanan makanan pada Situs 1 belum baik sedang pada situs 2 sudah baik. Asupan nutrisi pasien Situs 1 lebih rendah dibanding kebutuhan pasien, sedang pada Situs 2 lebih tinggi dari pada kebutuhan. Kerugian ekonomi akibat sisa makanan pada Situs 1 lebih tinggi dibanding Situs 2. Pelayanan gizi rumah sakit belum berjalan optimal, kerugian ekonomi akibat sisa makanan pasien masih tinggi. Rumah sakit diharapkan membuat kebijakan operasional pelayanan gizi rumah sakit agar pasien mendapat pelayan yang lebih adekuat.
\end{abstract}

Kata Kunci: Pelayanan gizi, pendekatan HTA, rumah sakit.

\section{Analysis of Nutritional Care in Hospital Using Health Technology Assessment Approach}

\begin{abstract}
Prevalence of malnutrition in hospital remain high, nutritional care assumption as one which responsible for this condition. This study aimed to assess of policy implementation of nutritional care inpatient hospital using health technology assessment approach. Research design was a case study with concurrent embedded mixed method strategy. Purposive sampling was chosen for the qualitative study and total sampling for quantitative study. Research was conducted at September until December 2014, at vertical hospital as Site 1 and secondery private hospital as Site 2. Quantitative data analisis was conducted descriptively, qualitative data analysis was using content analysis. Role of management in nutritional care was apparently appropriate enough. It was indicated by existence of nutritinal care team, and improvement of human resources quality. Technology of nutritional care at both sites have not met the standard of Ministry of Health. Perception of nutritional care quality at Site 1 was moderately good, perception patients of nutritional care quality at Site 2 was good. Nutritional's of intake of patient in Site 1 were lower than patient's need. Nutritional's of intake of patient in Site 2 were higher than patient's need. So, economic loss of leftovers at Site 1 was higher than Site 2. Nutritional care isn't running optimally. Economic loss cause by leftovers. Hospital is expected to establish operational policy of nutritional care, in order that patient get adequat care.
\end{abstract}

Keywords: HTA approach, nutritional care, hospital.

\footnotetext{
Korespondensi :

Dr. Dewi Marhaeni Diah Herawati, dr., M.Si

Departemen Ilmu Gizi Medik Fakultas Kedokteran Universitas Padjadjaran

Jl. Eijkman No. 38 Bandung

Mobile : 082126033975

Email : dewimdh@yahoo.com
} 


\section{Pendahuluan}

Pelayanan gizi baik berupa layanan asuhan gizi maupun penyelenggaraan makan bagi pasien di rumah sakit merupakan faktor yang sangat berperan dalam membantu proses penyembuhan penyakit. Jika pasien mendapat asupan gizi yang tepat selama menjalani perawatan di rumah sakit maka dapat membantu proses penyembuhan, mencegah terjadinya komplikasi, menurunkan morbiditas dan mortalitas. Dengan demikian dapat memperpendek lama hari rawat inap dan menekan biaya pengobatan. ${ }^{1}$ Saat ini banyak pasien yang menjalani rawat inap di rumah sakit Indonesia terjadi penurunan status gizi menjadi malnutrisi khususnya gizi kurang.,3 Penelitian yang dilakukan di Jerman menunjukkan hal yang sama. ${ }^{4}$ Kondisi ini disebabkan karena penyakit yang diderita pasien sudah dalam fase kritis, selain itu juga disebabkan karena kondisi internal pasien serta pelayanan gizi yang belum memadai. Faktor yang diduga memberi kontribusi dalam permasalahan malnutrisi di rumah sakit adalah pihak manajemen dan dokter rumah sakit yang masih memandang bahwa terapi gizi bukan merupakan bagian dari terapi penyakit. Faktor penyebab lainnya yang memberi kontribusi adalah kurangnya kapasitas dari tim asuhan gizi dan penyelenggara makan.

Pemerintah sesungguhnya sejak tahun 2006 telah membuat kebijakan tentang Pedoman Pelayanan Gizi Rumah Sakit melalui PerMenkes, namun ternyata kebijakan tersebut belum berjalan dengan baik. Pada tahun 2013 Pemerintah mengeluarkan PerMenkes No 78 Tahun 2013, ${ }^{1}$ sebagai penyempurnaan dari PerMenkes tahun 2006. Sampai saat ini belum pernah dilakukan penelitian terhadap pelaksanaan kebijakan pelayanan gizi di rumah sakit. Teori yang digunakan dalam melakukan asesmen adalah dengan pendekatan Health Technology Assessment (HTA).

HTA merupakan suatu cara yang paling tepat untuk melakukan penilaian baik dari sisi manajemen, teknologi, pasien serta kerugian ekonomi. ${ }^{5}$ Hasil penilaian HTA dapat digunakan pihak rumah sakit untuk melakukan perbaikan dalam mengatasi permasalahan malnutrisi. Penelitian yang dilakukan oleh Lassen et al menunjukkan bahwa perbaikan pelayanan gizi dapat dilaksanakan jika manejemen rumah sakit menjadikan pelayanan gizi sebagai masalah prioritas. Pihak profesional seperti dokter, perawat dan petugas gizi serta pengelola makanan harus memiliki kapasitas dan komitmen dalam melakukan pelayanan gizi. Pemberian pelayanan gizi yang baik dapat menghemat biaya sekitar $\$ 26.181$ per rumah sakit. ${ }^{6}$
Penelitian bertujuan untuk melakukan asesmen terhadap pelayanan gizi rumah sakit dengan pendekatan Health Technology Assessment (HTA) meliputi peran manajemen rumah sakit dalam pelayanan gizi, teknologi asuhan gizi dan penyelenggaraan makan, pandangan pasien terhadap mutu pelayanan gizi, kerugian ekonomi serta mengetahui asupan dan kebutuhan nutrisi pasien. Ruang lingkup penelitian adalah melakukan penilaian dari sisi proses dan out put bukan pada impact pelayanan gizi rumah sakit.

\section{Metode}

Desain penelitian adalah mixed method concurrent embedded,strategi penelitian kualitatif adalah studi kasus sedang penelitian kuantitatif adalah deskriptif cross sectional. Penelitian kualitatif untuk mengetahui peran manajemen, teknologi dalam pelayanan gizi serta persepsi dan pandangan pasien terhadap pelayanan gizi. Penelitian kuantitatif untuk mengetahui status gizi pasien sebelum perawatan dan setelah perawatan, asupan dan kebutuhan zat gizi baik energi, karbohidrat, lemak dan protein serta kerugian ekonomi.

Penelitian dilakukan di dua situs yaitu RS tertier sebagai Situs 1 dan RS skunder swasta di Bandung sebagai Situs 2. Situs 1 melihat pelayanan gizi pada pasien gagal ginjal kronik yang menjalani rawat inap, sedang Situs 2 melihat pelayanan gizi pada pasien diabetes mellitus yang menjalani rawat inap. Total subyek penelitian kualitatif ada 40 orang dengan rincian dari RS tertier ada 22 orang sedang RS skunder swasta ada 18 orang. Total subyek penelitian kuantitatif ada 47 orang dengan rincian dari RS tertier ada 25 orang sedang skunder swasta ada 22 orang. Waktu penelitian adalah bulan September 2014-Desember 2014. Pengambilan sampel kualitatif secara purposive sampling sedang sampel kuantitatif secara total sampling. Pengumpulan data kualitatif dilakukan melalui wawancara mendalam, sedang kuantitatif melalui data primer yaitu dengan melakukan food weighing serta data skunder melalui catatan medik pasien. Analisis data kuantitatif dilakukan secara deskriptif untuk mengetahui asupan gizi, kebutuhan gizi serta kerugian biaya dari sisa makanan. Analisis data kualitatif dilakukan secara content analysis. Uji validitas dan reliabilitas dilakukan melalui credibility, transferability, dependability dan confirmability. Penelitian ini telah mendapat ethical clearance dari Komite Etik FK Unpad dan telah memenuhi 4 aspek etik yaitu, respect for person, beneficence, maleficence dan justice. 


\section{Hasil}

Peran manajemen rumah sakit di Situs 1 dalam pemberian pelayanan gizi sudah cukup baik, hal ini terlihat dari telah dibentuknya Tim Asuhan Gizi (TAG) yang terdiri dari dokter, dietisien, perawat dan farmasi. Rumah sakit belum memiliki TAG khusus untuk melayani pasien gagal ginjal kronik. Rumah sakit belum memiliki UPF (Unit Pelayanan Fungsional) spesialis gizi karena belum memiliki dokter spesialis gizi. Pihak rumah sakit telah melakukan peningkatan sumber daya manusia (SDM) yang ada di instalasi gizi. Manajemen rumah sakit merasakan bahwa pelayanan gizi merupakan hal yang sangat penting dalam mendukung kesembuhan pasien. Peran manajemen rumah sakit di Situs 2 juga sudah cukup baik, mereka sedang berupaya untuk memperbaiki sistem pelayanan gizi. Pihak manajemen Rumah Sakit skunder swasta telah membentuk TAG, namun sampai saat ini TAG belum berfungsi dengan baik karena keterbatasan jumlah perawat dan dietisien. Rumah sakit juga belum memiliki UPF spesialis gizi karena belum ada dokter spesialis gizi, namun ada beberapa dokter spesialis gizi yang dikontrak untuk praktik dan menjadi konsultan dalam pelayanan gizi.

Tabel 1. Peran Manajemen di Rumah Sakit Situs 1 dan Situs 2

\begin{tabular}{lcc}
\hline Peran Manajemen RS & Situs 1 & Situs 2 \\
\hline Membentuk Tim & + & + \\
Asuhan Gizi (TAG) & & + \\
Kerjasama dg dokter & - & \\
SpGK & & - \\
UPF (Unit Pelyanan & - & \\
Fungsional) Spesialis & & + \\
Gizi & + & + \\
Instalasi Gizi & ++ & \\
Peningkatan SDM & & + \\
Instalasi Gizi & ++ & + \\
Komitmen & + & + \\
\hline
\end{tabular}

Perbedaan peran manajemen pada kedua situs terlihat dari peningkatan SDM Instalasi Gizi dan komitmen dalam mendukung pelayanan gizi lebih baik Situs 1 dari pada Situs 2. Peran manajemen rumah sakit dalam meningkatkan kualitas pelayanan gizi rumah sakit lebih baik Situs 2 dari pada Situs 1 dimana manajemen telah melakukan kerjasama dengan dokter spesialis gizi untuk praktik dan menjadi konsultan dalam pelayanan.

Teknologi pelayanan gizi ada 2 hal yaitu meliputi pelayanan asuhan gizi dan penyelenggaraan makan. Pelayanan asuhan gizi pada pasien gagal ginjal kronik yang menjalani rawat inap di Situs 1 telah mengikuti standar PAGT (Pelayanan Asuhan Gizi Terstandar) yang dibuat Kemenkes, namun belum seluruh pasien gagal ginjal kronik mendapat PAGT. Adapun instrumen yang digunakan adalah ADIME (asesmen, diagnosis, intervensi, monitoring dan evaluasi). Setiap pasien yang menjalani rawat inap, dilakukan skrining gizi terlebih dahulu oleh perawat untuk mendeteksi apakah pasien berisiko atau tidak berisiko malnutrisi, adapun waktunya paling lama 1x24 jam sejak pasien masuk rumah sakit. Penanganan pasien berisiko malnutrisi dilakukan oleh dietisien. Tahap selanjutnya adalah dilakukan pengkajian status gizi dan diagnosis gizi oleh dietisien. Setelah itu dilakukan rencana intervensi melalui pembuatan preskripsi oleh DPJP (Dokter Penanggung Jawab Pasien). DPJP menulis resep diet pasien dan diberikan kepada dietisien. Dietisien menerjemahkan preskripsi DPJP dalam bentuk menu makan sesuai kebutuhan pasien. Selanjutnya, tim pelayanan rawat inap yang terdiri dari perawat dan dietisien akan menulis DPMP (Daftar Permintaan Makanan Pasien) berdasarkan preskripsi dokter. DPMP tersebut dikirim ke bagian penyelenggara makan yang berada di instalasi gizi. Beberapa DPJP tidak terlalu paham dalam membuat preskripsi awal, hal tersebut dapat menimbulkan pemberian diet yang tidak tepat. Tahap selanjutnya adalah monitoring nafsu makan dan asupan makan pasien. Tahap akhir adalah evaluasi untuk menentukan keberlanjutan dari pelayanan asuhan gizi. Monitoring dan evaluasi belum berjalan dengan baik karena belum ada program dan jadwal kegiatan. Instalasi gizi telah membuat SOP (Standar Operating Procedur) untuk layanan asuhan gizi, penyusunan menu, pengelolaan produksi dan distribusi, penanganan makanan dan alat makan untuk pasien dengan penyakit menular, penyimpanan dan penanganan bahan makanan

Penyelenggaraan makan di Situs 1 dilakukan secara swakelola dan semi outsourcing. Adapun mekanisme penyelenggaraan makan dimulai dari perencanaan, pengadaan makanan dan bahan makanan, penyimpanan bahan makanan, pengolahan dan distribusi. Perencanaan makan menggunakan siklus pendek yaitu sekitar 10 hari. Pada proses pelayanan makanan, petugas pemorsi makanan sering memberikan porsi makanan tidak sesuai standar, makanan yang diberikan kepada pasien lebih banyak dari pada kebutuhan pasien. Petugas penyaji makanan telah bekerja sesuai protap, karena pada saatmengantarmakanan selalu melakukan pengecekan identitas pasien sehingga kesalahan pemberian menu dapat dihindari.

Pelayanan asuhan gizi pada pasien diabetes mellitus yang menjalani rawat inap di RS 
Situs 2 telah menggunakan standar PAGT dari Kemenkes, instrumen yang digunakan adalah ADIME. Sebelum dilakukan ADIME, setiap pasien yang baru masuk dilakukan skrining gizi oleh dietisien untuk mendeteksi apakah pasien berisiko atau tidak berisiko malnutrisi. Skrining yang dilakukan perawat untuk melihat riwayat penyakit, kondisi pasien serta melakukan pemeriksaan laboratorium. Waktu skrining bisa lebih dari 1x24 jam karena dietisien tidak berada 24 jam di rumah sakit. Rumah sakit di Situs 2 belum memiliki format khusus untuk skrining gizi. Tahap berikutnya adalah dilakukan pengkajian, dimana dietisien berkoordinasi dengan perawat mengenai hasil pemeriksaan fisik dan laboratorium. Dietisien juga melakukan pengkajian kebiasaan makan dan alergi makanan pada pasien. Diagnosis gizi dilakukan oleh dietisien. DPJP membuat preskripsi untuk diet pasien, pada umumnya DPJP hanya menentukan jumlah kalori dan bentuk makanan sedang jumlah zat gizi yang lain serta jenis makanan ditentukan oleh instalasi gizi. Monitoring dan evaluasi pelayanan gizi dilakukan oleh dietisien dengan mengukur kebutuhan makanan dan sisa makanan.

Penyelenggaraan makan di rumah sakit Situs 2 dilakukan secara swakelola oleh instalasi gizi, sehingga peran instalasi gizi ada dua yaitu memberikan asuhan gizi terstandar serta menyelenggarakan makan untuk pasien. Namun demikian instalasi gizi tidak merasa berat dengan tugas tersebut. Kegiatan perencanaan menu sampai dengan distribusi dilakukan oleh pihak instalasi gizi. Dietisien pada umumnya diberi tugas untuk memberikan layanan asuhan gizi, membuat perencanaan menu serta konsultasi gizi. Perencanaan menu dilakukan oleh kepala instalasi gizi, dietisien dan bagian produksi. Perencanaan kebutuhan, anggaran serta pemesanan dan pembelian bahan makanan menjadi tanggung jawab kepala instalasi gizi. Penerimaan dan penyimpanan bahan makanan dilakukan oleh petugas gudang, sedang pengolahan makanan dilakukan oleh petugas produksi. Pengolahan dan pemasakan menu diet untuk pasien diabetes mellitus sama dengan pasien yang lain, kecuali makanan kecil. Makanan kecil untuk pasien diabates mellitus tidak menggunakan gula sederhana, namun menggunakan susu skim sehingga proses pembuatannya dipisah dengan pasien lainnya. Distribusi makanan dilakukan oleh petugas penyaji. Penyaji akan membuat porsi makanan untuk pasien berdasar jumlah kalori yang telah dituliskan dalam rekam medis pasien. DPJP atau dietisien kadang-kadang lupa menuliskan jumlah kalori yang harus dikonsumsi pasien diabetes mellitus, akibatnya penyaji membuat porsi makanan sebanyak 1500 kalori.
Tabel 2. Teknologi Pelayanan Gizi di Rumah Sakit Situs 1 dan Situs 2

\begin{tabular}{|c|c|c|}
\hline $\begin{array}{c}\text { Teknologi } \\
\text { Pelayanan Gizi }\end{array}$ & Situs 1 & Situs 2 \\
\hline \multicolumn{3}{|l|}{$\begin{array}{l}\text { 1. Layanan } \\
\text { Asuhan Gizi }\end{array}$} \\
\hline a. Skrining & $\begin{array}{l}\text { Waktu 1x24 } \\
\text { jam, oleh } \\
\text { perawat, ada } \\
\text { form }\end{array}$ & $\begin{array}{l}>24 \text { jam, } \\
\text { oleh dietisien, } \\
\text { belum ada } \\
\text { form }\end{array}$ \\
\hline $\begin{array}{l}\text { b. ADIME } \\
\text { (Asesmen, } \\
\text { Diagnosis, } \\
\text { Intervensi dan } \\
\text { Monev) }\end{array}$ & $\begin{array}{l}\text { Belum } \\
\text { semua pasien } \\
\text { dilakukan } \\
\text { asesmen, } \\
\text { diagnosis dan } \\
\text { intervensi, } \\
\text { kegiatan monev } \\
\text { sudah berjalan } \\
\text { namun belum } \\
\text { rutin }\end{array}$ & $\begin{array}{l}\text { Semua pasien } \\
\text { telah dilakukan } \\
\text { asesmen, } \\
\text { diagnosis dan } \\
\text { intervensi, } \\
\text { namun } \\
\text { kegiatan } \\
\text { monev belum } \\
\text { berjalan }\end{array}$ \\
\hline $\begin{array}{l}\text { c. Koordinasi } \\
\text { Tim }\end{array}$ & $\begin{array}{l}\text { Sudah berjalan, } \\
\text { tetapi belum } \\
\text { optimal }\end{array}$ & Belum berjalan \\
\hline $\begin{array}{l}\text { d. Komunikasi } \\
\text { Tim }\end{array}$ & $\begin{array}{l}\text { Sudah berjalan, } \\
\text { tetapi belum } \\
\text { efektif }\end{array}$ & Belum berjalan \\
\hline e. SOP & Lengkap & $\begin{array}{l}\text { Kurang } \\
\text { lengkap }\end{array}$ \\
\hline \multicolumn{3}{|l|}{$\begin{array}{l}2 . \\
\text { Penyelenggara } \\
\text { Makan }\end{array}$} \\
\hline $\begin{array}{l}\text { a. Sistem } \\
\text { Pengelolaan }\end{array}$ & $\begin{array}{l}\text { Swakelola } \\
\text { dan semi } \\
\text { Outsourcing }\end{array}$ & Swakelola \\
\hline $\begin{array}{l}\text { b. Pengolahan } \\
\text { menu makanan }\end{array}$ & $\begin{array}{l}\text { Menu berbeda } \\
\text { dg pasien lain }\end{array}$ & $\begin{array}{l}\text { Menu sama } \\
\text { dengan pasien } \\
\text { lain }\end{array}$ \\
\hline c. Distribusi & $\begin{array}{l}\text { Sistem } \\
\text { desentralisasi, } \\
\text { pemorsi belum } \\
\text { sesuai standar, } \\
\text { penyaji selalu } \\
\text { mengecek } \\
\text { identitas pasien }\end{array}$ & $\begin{array}{l}\text { Sistem } \\
\text { desentralisasi, } \\
\text { jika tidak } \\
\text { preskripsi } \\
\text { dokter maka } \\
\text { pemorsi sering } \\
\text { membuat } \\
\text { asumsi sendiri }\end{array}$ \\
\hline
\end{tabular}

Persepsi pasien di rumah sakit Situs 1 terhadap mutu pelayanan makan secara keseluruhan belum optimal terutama dalam hal variasi dan cita rasa makanan. Pasien menginginkan peningkatan layanan makanan. Variasi makan yang monoton dan cita rasa yang kurang enak menyebabkan sisa makanan cukup banyak, karena pasien kehilangan selera makan dan nafsu makan. Pada umumnya 
pasien memilih membeli makanan dari luar rumah sakit, akibatnya petugas tidak dapat mengontrol asupan makan pasien. Namun demikian dalam hal waktu penyajian makan tepat waktu, alat makan memadai, petugas penyaji sopan dan perhatian kepada pasien serta penampilan makan bagus dan bersih. Hasil tersebut sesuai dengan hasil observasi yang dilakukan peneliti.

Persepsi pasien di rumah sakit Situs 2 terhadap mutu pelayanan makan lebih baik dari pada Situs 1. Menurut persepsi pasien, menu makan cukup bervariasi, penampilan makanan menarik dan menggugah selera, porsi makan pas, cita rasa makanan enak, aroma tidak mengganggu dan tekstur makanan tepat, waktu pemberian makan tepat, tempat makan bersih dan makanan disajikan dalam keadaan tertutup serta petugas sopan dan baik. Beberapa pasien mengatakan bahwa tidak semua makanan disajikan dalam keadaan hangat utamanya untuk makanan pokok dan lauk pauk. Pasien menginginkan ada petugas yang datang ketika pasien makan, untuk memberikan motivasi dalam menghabiskan makanan.

Makanan yang disajikan untuk pasien rawat inap meliputi makan pagi, makanan selingan antara pagi dan siang, makan siang, makanan selingan antara siang dan malam serta makan malam. Rata-rata biaya yang dibutuhkan untuk makan pasien per hari di rumah sakit Situs 1 sekitar Rp 15.419,- Pada umumnya makanan selingan tidak bersisa, namun untuk makan pagi, siang dan malem makanan selalu bersisa. Sisa makanan paling banyak terdapat pada makan pagi, dibanding makan siang dan malam. Berdasar hasil perhitungan, rata-rata kerugian ekonomi akibat sisa makanan pada pasien hemodialisis yang menjalani rawat inap di rumah sakit Situs 1 sebesar Rp 2.011 per pasien per hari atau sekitar $13 \%$ dari biaya makan pasien. Saat ini diperkirakan jumlah total kunjungan rawat inap di rumah sakit Situs 1 sekitar 59.394 pasien/ tahun, jika sisa makanan seluruh pasien dianggap sama maka rumah sakit akan mengalami kerugian ekonomi sebesar Rp 119.441.334/tahun.

Rata-rata kerugian ekonomi akibat sisa makanan pasien diabetes mellitus yang menjalani rawat inap di rumah sakit Situs 2 sebesar Rp 2.060 atau sekitar 8,72\% dari biaya makan. Jika seluruh pasien rawat inap pada berbagai kasus dianggap memiliki sisa makanan yang sama, maka dengan jumlah total kunjungan pasien rawat inap sekitar 21.745 pasien/tahun, diperkirakan rumah sakit akan mengalami kerugian ekonomi sebesar Rp. 44.974.700,-. Jumlah asupan energi, karbohidrat, lemak dan protein pada pasien gagal

Tabel 3. Mutu Pelayanan Makanan di Rumah Sakit Situs 1 dan Situs 2 Berdasarkan Persepsi Pasien

\begin{tabular}{|c|c|c|}
\hline $\begin{array}{c}\text { Persepsi Mutu Makanan } \\
\text { Menurut Pasien }\end{array}$ & Situs 1 & Situs 2 \\
\hline Variasi menu makan & Kurang variatif & Cukup variatif \\
\hline $\begin{array}{l}\text { Cara penyajian makan: } \\
\text { penampilan, porsi dan makanan } \\
\text { sesuai permintaan pasien }\end{array}$ & Kurang baik & Baik dan tepat \\
\hline $\begin{array}{l}\text { Cita rasa: aroma, tekstur, suhu dan } \\
\text { rasa makanan }\end{array}$ & Kurang enak, suhu kurang hangat & $\begin{array}{l}\text { Cita rasa makan enak namun suhu } \\
\text { tidak selalu hangat }\end{array}$ \\
\hline $\begin{array}{l}\text { Ketepatan waktu menghidangkan } \\
\text { makanan }\end{array}$ & Tepat waktu & Tepat waktu \\
\hline Keadaan tempat makanan & Memadai & Memadai dan tempat tertutup \\
\hline Kebersihan makanan & Baik & Baik \\
\hline $\begin{array}{l}\text { Sikap dan perilaku petugas yang } \\
\text { menghidangkan }\end{array}$ & Sopan dan penuh perhatian & Sopan dan ramah \\
\hline Monitoring petugas saat makan & Tidak ada & Tidak ada \\
\hline
\end{tabular}


Tabel 4. Jumlah Asupan dan Kebutuhan Gizi Pada Pasien Yang Menjalani Rawat Inap di RS Situs 1 dan Situs 2

\begin{tabular}{ccccc}
\hline Zat Gizi & \multicolumn{2}{c}{ Pasien hemodialiasi di RS Situs 1 } & \multicolumn{2}{c}{ Pasien DM di RS Situs 2 } \\
\cline { 2 - 5 } & Jumlah Asupan & $\begin{array}{c}\text { Jumlah } \\
\text { Kebutuhan }\end{array}$ & Jumlah Asupan & $\begin{array}{c}\text { Jumlah } \\
\text { Kebutuhan }\end{array}$ \\
\hline Energi & 1204,6 & 1509,4 & 1814,37 & 1515,89 \\
Karbohidrat & 108 & 245,5 & 228,66 & $227,38-265,28$ \\
Lemak & 26 & 32,9 & 68,32 & $42,11-50,53$ \\
Protein & 38 & 59,3 & 85,64 & $56,19-76,31$ \\
Natrium & & & 3264,01 & $<2300$ \\
Serat & & & 111,76 & $25-50$ \\
\hline
\end{tabular}

ginjal kronik di rumah sakit Situs 1 jauh lebih rendah dibanding kebutuhan pasien.

Jumlah asupan energi, lemak, protein, natrium dan serat pada pasien diabetes mellitus di rumah sakit Situs 2 lebih besar dari pada jumlah kebutuhan, namunasupankarbohidratlebihrendah dari pada kebutuhan pasien. Adapun perhitungan jumlah asupan gizi pasien dilakukan dengan menggunakan food weighing, sedang kebutuhan gizi dihitung berdasarkan standar yang ada.

\section{Pembahasan}

Peran manajer rumah sakit Situs 1 lebih baik dari pada Situs 2, namun peran tersebut belum optimal. Keberadaan TAG di rumah sakit merupakan bentuk dukungan yang diberikan oleh pihak manajemen rumah sakit dalam mengatasi pasien yang mengalami malnutrisi. Namun keberadaan TAG di rumah sakit Situs 1 baru dilakukan pada pasien-pasien bedah, belum dilakukan pada semua pasien termasuk pasien hemodialisis.

TAG rumah sakit Situs 2 belum berjalan, disebabkan karena tidak adanya UPF dokter spesialis gizi klinik. Pihak manajemen sesungguhnya telah melakukan kerjasama dengan dokter spesialis gizi untuk praktik di rumah sakit. Pasien yang dirujuk atau dikonsultasikan kepada dokter spesialis gizi adalah kasus yang sulit dan tidak bisa ditangani oleh DPJP. Hal tersebut menyebabkan tidak semua pasien DM mendapatkan pelayanan gizi dari dokter yang berkompetensi di bidang gizi klinik.

Seluruh manajemen rumah sakit di Situs 1 maupun Situs 2 harus mampu meningkatkan pengawasan internal dalam pelayanan gizi untuk seluruh pasien terutama terhadap pemberian preskripsi dan menu diet. Harapannya agar preskripsi dan menu diet dapat diberikan dengan tepat dan sesuai dengan kondisi penyakit serta keinginan pasien. Seluruh pihak manajemen rumah sakit juga harus paham bahwa pelayanan gizi rumah sakit merupakan bagian yang sangat penting dan menjadi salah satu faktor yang mendukung perawatan dan penyembuhan pasien. Oleh karena itu seluruh SDM dalam pelayanan gizi perlu ditingkatkan baik melalui pendidikan maupun pelatihan.

Teknologi pelayanan gizi di rumah sakit merupakan satu sistem yang panjang dan kompleks sehingga dibutuhkan sumber daya manusia yang kompeten dari berbagai kualifikasi tenaga, selain itu juga dibutuhkan sarana dan prasarana yang cukup serta dukungan dari manajemen rumah sakit. Adanya kelemahan dari salah satu sistem dalam pelayanan gizi dapat berdampak pada asupan zat gizi pasien yang tidak adekuat sehingga status kesehatan pasien menjadi menurun.

Skrining gizi pasien di rumah sakit Situs 2 masih dilakukan oleh dietisien karena belum ada format yang dapat dipakai sebagai panduan pelaksaanan skrining gizi oleh perawat. Skrining gizi idealnya dilakukan oleh perawat ruangan dan diikuti dengan preskripsi diet awal oleh dokter. ${ }^{1}$ Skrining penting dilakukan karena untuk melihat perubahan berat badan, nafsu makan, gangguan intestinal dan asupan makanan.

Peran TAG untuk pasien hemodialisis di rumah sakit Situs 1 nampak belum optimal. Pelayanan gizi di rumah sakit akan berjalan dengan baik jika ada koordinasi antar profesi. Komunikasi setiap bagian yang terlibat dalam pelaksanaan pelayanan gizi diperlukan untuk memberikan asuhan gizi yang terbaik bagi pasien. ${ }^{1,7}$ Pelayanan tim terapi gizi membutuhkan kerjasama multidisiplin untuk merealisasikan pelayanan gizi yang berkualitas, pencegahan dan perbaikan kurang gizi serta penurunan morbiditas. ${ }^{7}$

Penyelenggaraan makanan di rumah sakit Situs 1 dilakukan dengan swakelola dan semi outsourcing, sedangkan di rumah 
saki Situs 2 menggunakan sistem swakelola. Mekanisme penyelenggaraan makanan sudah sesuai standar yang dibuat Kemenkes. ${ }^{1}$ Penyelenggara makan harus dapat melakukan upaya-upaya perbaikan dan edukasi pada pasien agar pelayanan makanan di rumah sakit sesuai dengan kebutuhan dan harapan pasien.

Koordinasi dari berbagai elemen mulai dari pihak manajemen serta TAG harus dilakukan agar pasien mendapat asupan makanan yang adekuat selama dirawat di rumah sakit. Pasien dengan kondisi gizi kurang membutuhkan pelayanan gizi berbeda dengan pasien yang memiliki kondisi gizi lebih, pasien hemodialisis membutuhkan pelayanan gizi yang berbeda dengan pasien diabetes mellitus, stroke, jantung dan lain-lain. Tim asuhan gizi mulai DPJP, dietisien, perawat, instalasi gizi dan penyelenggara makan sebaiknya meningkatkan kapasitas dan kepedulian dalam terapi gizi. Pelayanan gizi bertujuan untuk meningkatkan atau mempertahankan daya tahan tubuh pasien, oleh karena itu makanan yang disajikan haruslah memiliki kandungan gizi yang seimbang sesuai dengan penyakit dan status gizi masing-masing pasien.

Rendahnya asupan makan pada pasien hemodialisis yang menjalani rawat inap disebabkan faktor internal dan eksternal pasien. Penyebab faktor eksternal antara lain karena menu makan yang dihidangkan kurang bisa menggugah selera makan pasien, preskripsi yang dibuat DPJP belum sesuai dengan kebutuhan pasien, belum adanya TAG khusus untuk pasien hemodialisis. Penyebab faktor internal karena pasien mengalami anoreksia dan mual karena proses dialisis yang dialaminya, oleh sebab itu pasien mengalami penurunan nafsu makan yang berat. 8 Rendahnya asupan makan pasien berakibat pada tingginya jumlah sisa makan sehingga berdampak pada kerugian ekonomi. Asupan energi pasien hemodialisis dan menjalani rawat inap harus sama dengan kebutuhan pasien, dimana menurut K/DOQI adalah $35 \mathrm{kkal} / \mathrm{kg}$ $\mathrm{BB} /$ hari.9. Asupan energi yang kurang dari kebutuhan pasien dapat mengakibatkan pasien menjadi malnutrisi. Asupan protein pasien sangat penting dan dibutuhkan oleh pasien hemodialisis yang menjalani rawat inap, karena digunakan untuk menggantikan protein yang hilang selama dialisis. Adapun protein yang dibutuhkan adalah yang mengandung asam amino lengkap baik asam amino esensial maupun non esensial. ${ }^{9}$

Asupan makan pada pasien DM lebih besar dari pada kebutuhan pasien, terutama asupan energi, lemak, protein dan natrium. Hal tersebut menunjukkan bahwa TAG mulai dari DPJP, dietisen, perawat, instalasi gizi beserta bagian dapur belum mampu memberikan terapi gizi yang tepat untuk pasien. Intervensi gizi seharusnya merupakan bagian intervensi penyembuhan pasien yang bersifat komprehensif, karena memiliki daya ungkit yang paling besar dalam penyembuhan pasien. Asupan karbohidrat yang ideal adalah $60-70 \%$ dari jumlah energi total perhari, adapun diet karbohidrat yang tepat adalah yang berasal dari biji-bijian, buah dan sayuran..$^{10}$

Pasien sebaiknya menghindari makanan yang memiliki indeks glikemik yang tinggi seperti roti tawar, kentang bakar, kentang goreng, nasi putih pulen, tepung beras dan cornflakes. Asupan protein yang dianjurkan untuk pasien diabetes mellitus adalah $15-20 \%$ dari energi total per hari. ${ }^{11}$ Asupan lemak total idealnya adalah $25-30 \%$ dari total kebutuhan energi per hari. Pasien harus membatasi asupan asam lemak jenuh, asam lemak trans dan kolesterol agar tidak terkena penyakit kardiovaskuler. Pasien sebaiknya mengurangi asupan natrium, hal ini digunakan untuk mencegah terjadinya tekanan darah tinggi, adapun asupan yang dianjurkan untuk natrium adalah $<2000$ miligram per hari.

Pandangan pasien terhadap mutu pelayanan makanan menjadi salah satu penilaian dalam mutu pelayanan gizi rumah sakit. Mutu pelayanan gizi dapat dilihat dari perubahan status gizi dan banyaknya makanan yang tersisa. Instalasi Gizi rumah sakit Situs 1 dalam memberikan pelayanan makanan sudah cukup baik, namun belum memenuhi kebutuhan dan harapan pasien. Petugas pemorsian dalam melakukan tugasnya tidak menggunakan ukuran yang tepat sehingga porsi makan pasien sering kebanyakan dan menyebabkan jumlah sisa makanan tinggi. Variasi menu dirasakan pasien masih kurang, sehingga mengurangi selera makan pasien dan menyebabkan pasien tidak mau makan atau menghabiskan makanan rumah sakit.

Makanan yang disajikan kepada pasien di rumah sakit Situs 2 tidak semua bersuhu hangat. Distribusi makanan dari dapur ke pantry menggunakan troli yang tidak memiliki penghangat. Makanan pokok dan lauk pauk juga tidak dipanaskan kembali oleh petugas penyaji setelah didistribusikan ke pantry. Hal tersebut tidak sesuai dengan standar yang telah dibuat Kemenkes, karena makanan yang tidak dihangatkan kembali setelah didistribusikan ke pantry akan mengurangi kualitas. ${ }^{1}$ Sisa makanan pada pasien baik di rumah sakit Situs 1 maupun Situs 2 disebabkan karena kurangnya nafsu makan. Hal tersebut sesuai dengan penelitian di Inggris pada tahun 1995 yang menunjukkan bahwa $40 \%$ pasien menyisakan makanannya karena kehilangan nafsu makan. Penelitian Stanga, et al di Swiss menyatakan bahwa separoh dari pasien mengaku nafsu makannya menurun 
ketika dirawat inap di rumah sakit. ${ }^{12}$ Pasien perlu diberikan edukasi tentang pentingnya makanan untuk pengobatan, diharapkan agar dapat meningkatkan asupan makan pasien dan mengurangi jumlah sisa makanan. ${ }^{1}$

Sisa makanan pasien pada Situs 1 dan 2 masih berada dibawah standar yang ditetapkan Kemenkes yaitu kurang dari $20 \%$, namun demikian akan lebih baik jika pasien dapat menghabiskan makanannya, sehingga dapat membantu proses penyembuhan pasien. ${ }^{1}$ Kerugian akibat sisa makanan di rumah sakit Situs 1 diperkirakan sebesar Rp 119.441.334/ tahun, sedang rumah sakit Situs 2 sebesar Rp. 44.974.700,-. Kerugian akibat sisa makanan juga terjadi di RSUP Dr. Sarjito yaitu mencapai Rp 45.543.120/tahun,13 kerugian ini jauh lebih sedikit dibanding dengan hasil penelitian di rumah sakit Situs 1. Kerugian ekonomi ini seharusnya tidak boleh terjadi, uang yang hilang akan lebih bermanfaat untuk perbaikan diet pasien, agar pasien tidak makin malnutrisi. Pihak manajemen rumah sakit sebaiknya berupaya melakukan pemantauan secara reguler terhadap pelayanan gizi, sedang TAG dan penyelenggara makan harus berupaya untuk meningkatkan kapasitasnya agar dapat memberikan pelayanan gizi yang adekuat.

Rumah sakit Situs 1 maupun Situs 2 telah berupaya menjalankan kebijakan dari Kemenkes, namun masih banyak hambatan dan kendala yang dialami. Dalam menjalankan kebijakan pelayanan gizi, rumah sakit nampaknya membutuhkan kebijakan teknis. Hal ini penting dibuat, agar pelayanan gizi di rumah sakit dapat berjalan lebih baik karena ada komitmen dari pihak manajemen dan seluruh stakeholder rumah sakit.

Peran manajemen dalam pelayanan gizi di rumah sakit belum optimal, terutama dalam hal penyediaan UPF dokter spesialis gizi. Teknologi pelayanan gizi belum berjalan optimal, baik dalam layanan asuhan gizi maupun penyelenggaraan makan. DPJP (dokter penanggung jawab pasien) kurang tepat dalam membuat preskripsi pasien. Menu diet pasien belum bersifat individu dan sesuai dengan kasus penyakit pasien. Mutu pelayanan makan menurut persepsi pasien lebih baik di rumah sakit Situs 2 dari pada Situs 1. Asupan makan pasien belum sesuai dengan kebutuhan makan pasien. Kerugian ekonomi akibat sisa makanan cukup besar, rumah sakit tertier sekitar $\mathrm{Rp}$ 119.441.334/tahun sedang rumah sakit skunder Rp. 44.974.700. Implementasi kebijakan dapat berjalan dengan baik jika ada dukungan kebijakan yang lebih teknis dari pelaksana kebijakan.

Rumah Sakit segera menyusun kebijakan teknis tentang pelayanan gizi dimana didalamnya membahas tentang tim asuhan gizi dan tim penyelenggara makan baik kapasitas maupun kewajiban dan perannya. Mekanisme teknologi pelayanan gizi juga merupakan hal yang penting untuk dibahas. Peran manajemen rumah sakit perlu ditingkatkan terutama dalam hal pengawasan internal mutu pelayanan gizi.

$$
\text { Kementerian Kesehatan, Dinas }
$$

Kesehatan Provinsi dan Kabupaten/Kota: meningkatkan fungsi pengawasan dan fasilitasi dalam pelayanan gizi di rumah sakit sesuai dengan kewenanangannya, terutama dalam penyediaan SDM (dokter spesialis gizi, dietisien dan penyelenggara makan) serta sarana prasarana instalasi gizi.

\section{Daftar Pustaka}

1. Kementerian Kesehatan Republik Indonesia. Pedoman pelayanan gizi rumah sakit. Jakarta. 2013.

2. Budiningsari RD, Hadi H. Pengaruh perubahan status gizi pasien dewasa terhadap lama rawat inap dan biaya rumah sakit. Jurnal Gizi Klinik Indonesia. 2004; 1 (1): 35-45

3. Wahyuni S, Julia M, Budiningsari RD. Pengukuran status gizi pasien anak menggunakan metode Subjective Global Nutrition Assessment (SGNA) sebagai prediktor lama rawat inap, status pulang dan kejadian malnutrisi di rumah sakit. Jurnal Gizi Klinik Indonesia. 2005: 2 (1):1-5.

4. Leistra E, Neelemaat F, Evers AM, van Zandvoort MH, Weijs PJ, van der van Bokhorst-de SchuerenMA, etal: Prevalence of undernutrition in Dutch hospital outpatients. Eur J Intern Med. 2009; 20(5):509-513.

5. Kristensen FB, Sigmund H (Ed). Health technology assessment handbook. National board of health Denmark.2008.

6. Lassen $\mathrm{KO}$, Olsen J, Grinderslev E, Kruse F, Bjerrum M. Nutritional care of medical inpatients: a health technology assessment. BMC Health Services Research. 2006; 6:7.

7. Harney M. Food and Nutritional Care in Hospital: Guidelines for Preventing Under-Nutrition in Acute Hospitals. Departement of Health and Children. 2009.

8. IkizlerTA. Nutrition support for the chrinically wasted or acutely catabolic chronic kidney disease patient. Semin Nephrol.2009;1:75-84

9. National Kidney Foundation. K/DOQI clinical practice guidlines for bone metabolism and disease in chronic kidney disease. Am J Kidney Dis 2003;42(4 suppl 3):S1-201.

10. American Diabetes Association. Nutrition recommendations and intervention for diabetes. Diabetes Care Journal. 2008;31. 
11. Klein S, Sheard NF, Pi-Sunyer X, Daly A, Wylie-Rosett J, Kulkarni K, et ali. Weight management through lifestyle modification for the prevention and management of type 2 diabetes: rationale and strategies. A statement of the american diabetes association, the north american association for the study of obesity, and the american society for clinical nutrition. Am J Clin Nutr.2004;80:257-63.
12. Williams $\mathrm{P}$, Walton K. Plate Waste in Hospitals and Strategies for Change. The European E-Journal of Clinical Nutrition and Metabolism. 2011;6(6):235-41.

13. Djamaluddin M, Prawirohartono EP, Paramastri I. Analisis zat gizi dan biaya sisa makanan pada pasien dengan makanan biasa. Jurnal Gizi Klinik Indonesia. 2005;1: 108-12. 